Sains Malaysiana 48(3)(2019): 613-619

http://dx.doi.org/10.17576/jsm-2019-4803-14

\title{
Blood Inflammatory Markers, Anabolic Hormone, Vitamin D and L-Carnitine Status According to Frailty Status among Older Adults
}

(Penanda Inflamasi Darah, Hormon Anabolik, Vitamin D dan Status L-Karnitin menurut Status Keuzuran dalam Kalangan Warga Emas)

\author{
Manal Badrasawi, Suzana ShahaR*, Nor Fadilah Rajab \& DeVinder KaUR AJit Singh
}

\begin{abstract}
Frailty is associated with functional decline and reduced ability to cope with physiological challenges. The pathophysiological changes in frailty include inflammation, endocrine disturbances, neuromuscular and immune dysfunction. However, comprehensive information on the relationship between biological markers and frailty is scarce. We aimed to determine the relationship between selected biomarkers and frailty among Malaysian older adults. In this cross sectional study, 600 community dwelling older adults were randomly selected from ten different areas in Klang Valley. A total of 382 participants met the inclusion criteria and consented to the study. Out of these, a subsamples of 91 participants were selected for biomarkers analysis. Frailty was defined using Fried's criteria. Fasting blood glucose, lipid profile, albumin, selected frailty biomarkers including IL-6, TNF- alpha and IGF-1 and vitamin D together with free $L$-carnitine and acetyl L-carnitine were analysed. The results showed a significantly higher level of serum IL-6 and TNF- $\alpha$ among participants classified as frail as compared to pre-frail and robust $(\mathrm{p}<0.05)$. With respect to nutritional biomarkers, binary logistic regression showed that vitamin D deficiency is associated with three times higher risk of frailty $(\mathrm{p}<0.05)$. There was no significant relationship between blood L-carnitines and frailty. Further research is required to explore the relationship between $L$-carnitine and frailty using different parameters involved in L-carnitine homeostasis such as CPTII enzyme and OCTN2 mutation. In conclusion, frailty was associated with increased level of inflammatory markers and vitamin D deficiency. It is empirical to promote healthy lifestyle or disease management to reduce inflammation and increase vitamin D status as one of the frailty prevention action plan among older adults.
\end{abstract}

Keywords: Anabolic hormone; frailty biomarkers; inflammatory mediators; L-carnitine; vitamin D

\section{ABSTRAK}

Keuzuran adalah berkaitan dengan kemerosotan status kefungisan dan keupayaan dalam menangani cabaran fisiologi. Perubahan patofisiologi keuzuran termasuklah ketakfungsian ototneuro, ketakupayaan fungsi imun, inflamasi dan gangguan endokrin. Namun begitu, tidak banyak penyelidikan yang mengkaji hubungan antara petunjuk biologi dan keuzuran secara menyeluruh. Oleh itu, kajian ini menentukan hubungan antara petunjuk biologi tertentu dan status keuzuran dalam kalangan warga emas. Seramai 600 orang warga emas daripada komuniti dipilih secara rawak dari 10 buah kawasan di Lembah Klang. Seramai 382 peserta memenuhi kriteria kajian dan bersetuju mengambil bahagian. Seramai 91 subjek dipilih daripada sampel keseluruhan untuk analisis petunjuk biologi. Keuzuran didefinasikan daripada kriteria Fried. Petunjuk biokimia keuzuran yang dikaji termasuk IL-6, TNF- alfa dan IGF-1 serta vitamin D, bersamasama dengan L-karnitin bebas dan asetil L-karnitin dianalisis. Keputusan menunjukkan aras plasma darah IL-6 dan TNF- $\alpha$ adalah lebih tinggi secara signifikan dalam kumpulan uzur berbanding, prauzur dan robus $(\mathrm{p}<0.05)$. Berhubung dengan petunjuk biologi pemakanan, analisis logistik binari menunjukkan kekurangan vitamin D berkaitan dengan risiko keuzuran sebanyak tiga kali ganda $(\mathrm{p}<0.05)$. Tiada hubungan signifikan antara L-karnitin dalam plasma darah dengan keuzuran, oleh itu, penyelidikan lanjut diperlukan untuk mengkaji hubungan antara homeostasis L-karnitin seperti enzim CPTII dengan mutasi OCTN2. Kesimpulannya, keuzuran dikaitkan dengan peningkatan tahap penanda inflamasi dan kekurangan vitamin D. Terdapat keperluan untuk meningkatkan strategi promosi gaya hidup sihat atau pengurusan penyakit untuk menurunkan tahap keradangan dan meningkatkan aras vitamin D bagi mencegah keuzuran dalam kalangan warga emas.

Kata kunci: Keuzuran; L-karnitin; pengantara inflamasi; petunjuk biologi; vitamin D

\section{INTRODUCTION}

Frailty is a distinct clinical syndrome with a biological basis (Lang et al. 2010). It is defined as loss of ability to adapt to stress as a result of diminished functional reserves
(Weiss 2011) and declined ability to maintain homeostasis (Byard 2015). The pathogenesis of frailty involves numerous physiological adaptive response that include inflammation, neuromuscular dysfunction, endocrine 
dysregulation, immune dysfunction, abnormalities in energy metabolism (Crenstil 2010) and central nervous system failure (Mocchegiani et al. 2010).

Screening for frailty among older adults in clinical practice is limited probably due to the time consuming methods of doing so using standard validated tools (Annweiler et al. 2011). It has been suggested that the identification of blood markers that distinguish at-risk frail older adults would be useful for the purpose of both prevention and etiological studies (Collerton et al. 2012). In addition, evidence suggested that physiological changes are obvious in preclinical stage of frailty (prefrailty). It is hypothesized that these alterations are responsible for the characteristics that are used to classify the syndrome (Shamsi et al. 2012).

Understanding the mechanisms of aging and age-related disorders helps in comprehending frailty pathophysiology mechanism (Chung et al. 2009). The available evidence strongly suggests that the interactions between inflammatory pathway, endocrine regulation, mitochondria function, nutrition and genes are very important in molecular and physiological changes that contribute to the development of frailty in older adults (Mocchegiani et al. 2010). Based on the suggested mechanisms and etiology of frailty and related pathophysiological changes, several biological markers have been proposed as frailty biomarkers (Kumar et al. 2014).

The relationship between inflammatory mediators and oxidative stress with frailty, mainly Interleukin-6 (IL-6), tumor necrosis factor- $\alpha$ (TNF- $\alpha$ ), C-reactive protein (CRP), homocysteine and oxidative stress has been examined (Lai et al. 2014). Significant relationships were reported with higher level of IL-6 (Almeida et al. 2012; Collerton et al. 2012; Lai et al. 2014), whilst the relationships with higher level of CRP and TNF- $\alpha$ were controversial. Other frailty biomarkers that have been studied are anabolic hormone IGF-1 (Leng et al. 2009); immune function (Collerton et al. 2012); micronutrients mainly vitamin D (Chang et al. 2010; Vogt et al. 2015); vitamin E (Ble et al. 2006); presence of heavy metal toxicity (García-Esquinas et al. 2015); visceral protein (Collerton et al. 2012; Hubbard \& Woodhouse 2010); multisystem function kidney, liver function and lipid profile (Fernández-Garrido et al. 2014); and telomere length (Telomeres are repetitive DNA sequences at the ends of the chromosomes that protect the DNA against degradation and maintain chromosomal stability) (Saum et al. 2014). Yet, there is no gold standard biomarker for frailty that can be used to predict and prevent frailty, or used in etiological studies (Annweiler et al. 2011).

L-carnitine is a non-essential nutrient, fundamental to cellular energy metabolism, synthesized in the liver, kidney and brain through the conversion of two essential amino acids, lysine and methionine (Crentsil 2010). L-carnitine deficiency is associated with persistent inflammatory state and immune dysregulation in or for some diseases (Campos et al. 1995). Crenstil (2010) has proposed a relationship between L-carnitine deficiency and frailty through several mechanisms including its effect on skeletal muscle metabolism, hyperinflammation, energy production and immune cells function. L-carnitine plays an obligatory role in mitochondrial function in oxidation of long-chain fatty acids. Serum fatty acid was found to be higher with increasing age, and the ratio of omega 3 to omega 6 fatty acid was significantly lower in older adults (Hall \& Jewell 2012). This might explain the mild proinflammatory state often found in older adults (Hall \& Jewell 2012).

In addition, L-carnitine deficiency may lead to frailty through mitochondria dysfunction manifested by weakness, sarcopenia and fatigue which are components of frailty. Another important point is that muscle weakness is a major characteristic of frailty. L-carnitine deficiency can affect skeletal muscle function by its role in beta oxidation, the main energy source for skeletal muscle (Crentsil 2010). High serum L-carnitine levels were also found to be correlated with better functional abilities (Brass 2001). However, L-cranitine serum level has not been extensively studied among frail or prefrail compared to robust older adults. We aimed to determine the status of suggested frailty biomarkers such as IL-6, TNF- $\alpha$ IGF-1 and vitamin $\mathrm{D}$ among the three groups of older adults (frail, prefrail and robust), and to examine the plasma level of L-carnitine as a potential biomarker for frailty.

\section{MATERIALS AND METHODS}

This study is a part of larger cross sectional study conducted in Klang Valley, Malaysia as reported earlier in Shahar et al. (2015). Ethical approval was obtained from Universiti Kebangsaan Malaysia Medical Research and Ethics Committee (UKM 1.5.5.5/244/NN-149-2013). Participants were selected by multistage random sampling from nine rural and urban districts, of which the percentage of older adults was $10 \%$ and above. More than 600 Malaysian older adults aged 60 years and above, were personally invited to participate in this study. A total of 574 respondents agreed to join the study and signed the consent form. The response rate was $92.5 \%$. A total of 382 participants met the inclusion criteria and consented to provide their blood for biochemical analysis. Out of this figure, a sub samples of 91 participants were selected from the; frail, prefrail and robust groups. All of the respondents from the frail group were included, and the selected prefrail and robust groups were then matched for age, gender, educational level, economic status and ethnicity.

Frailty was defined using Fried's criteria which is widely used in clinical research and for frailty assessment (Rockwood et al. 2007). It was developed in a very large prospective study (Fried et al. 2001) involving 5000 elderly individuals, aiming to develop and validate a phenotype of frailty in older adults. Shrinking, exhaustion, weakness, slowness and low physical activity were concluded as the assessment criteria. Participants with three or more $(\geq 3)$ criteria were defined as frail; with one or two (1 or 2 ) as prefrail; and with zero (0) as robust (Fried et al. 2001). 
In order to obtain accurate and standard biochemical tests, the respondents were asked to fast overnight. Peripheral venous blood samples from the respondents were collected by a trained phlebotomist. A total of 20 $\mathrm{mL}$ blood was collected in tubes and kept in an ice box until it was transferred to the lab. Albumin, fasting blood sugars (FBS), glycosylated hemoglobin (HBA1c) and lipid profile were conducted at the Path Lab-Pathology and Clinical Laboratory, Sdn Bhd - Klang Valley branches Malaysia, for quick analysis. The remaining blood, serum and plasma were aliquoted at the Path Lab, then transferred and stored in freezer at $\left(-80^{\circ} \mathrm{C}\right)$ located at the food analysis Lab- Faculty of Health Sciences-UKM, for further analysis. Selected frailty biomarkers including IL-6, TNF- $\alpha$ and IGF-1 in addition to vitamin $\mathrm{D}$ were analyzed to determine their relationship with frailty. IL-6, TNF- $\alpha$, IGF-1 and vitamin $\mathrm{D}$ were detected using the blood serum, while the free, total and the acetyl L-carnitine were analyzed using blood plasma.

The plasma level of L-carnitine and total L-carnitine were done using a validated method (Prieto et al. 2006). It is an easy and accurate method to measure the L-carnitine status in human plasma using spectrophotometric analysis. The chemicals were purchased from two companies: MERCK SDN BHD and Sigma SDN BHD. The chemicals from MERCK were L-carnitine for synthesis, Acetylcoenzyme A, Trillium salt, (70-72\%) Perchloric acid, Potassium Hydroxide pellets for analysis, Hydrochloric acid, and Sodium Carbonate anhydrous for analysis. Disodium EDTA, 5,5'- dithio-bis (2-Nitrobenzoic acid) DTNB and 4-(2-hydroxyethyl) -1-piperazineethanesulfonic acid HEPES; while Carnitine acetyle transferase chemical was bought from Sigma. The steps of the analysis were done following Prieto et al. (2006) protocol. The L-carnitine insufficiency was defined by the value of free L-carnitine: acetyl L-carnitine ratio less than 0.4 as suggested by Calabrese et al. (2006). The detection of IL-6, TNF- $\alpha$, IGF-1 and vitamin D in the serum was done using Enzyme-linked Immunosorbent Assays kit (R\&D systems, USA). The samples and reagents preparation and assay procedures were done following the kits manual provided by the company. Vitamin D deficiency was defined by value of 25(OH)D serum level ( $<25 \mathrm{nmol} / \mathrm{l})$ (Vogt et al. 2015).

All statistical analyses were performed using the Statistical Package for Social Sciences (SPSS) software, version 21.0. An alpha level of (0.05) was considered for all the statistical tests in the study. Two sided $\mathrm{p}$ values of $(0.05)$ and $(80 \%)$ power were considered to be statistically significant. Normality test showed that the data was not normally distributed. The mean differences between the three groups (frail, prefrail and robust) were tested using Kruskal Wallis test as the data was not normally distributed. For categorical variables, Chi square test was employed to determine the association between frailty status and the categorical variables (Vitamin D and L-carnitine deficiency). Binary logistic regression was done to determine frailty predictors. The multicollinearity, outliers and goodness of fit tests was employed to assess how well the model fit the data (Field 2013).

\section{RESULTS AND DISCUSSION}

The results showed that participants mean age was $68 \pm 5.9$ years and there were no significant differences between the three groups in term of gender, age, race and economic status as shown in Table 1.

The mean of albumin, fasting blood sugars and lipid profiles were not statistically different between the three groups (frail, prefrail and robust), as shown in Table 2.

Regarding frailty biomarkers, some of the selected frailty biomarkers differed statistically between the three groups. The mean inflammatory mediators (IL- 6 and TNF- $\alpha$ ) were higher in frail as compared to prefrail and robust group ( $p<0.05$ for all parameters). Similar trend was found in IGF-1 but the differences did not reach a significant level. Vitamin D deficiency was higher in frail (85\%), followed by prefrail $(76.6 \%)$ and robust $(54.5 \%)$ group $(p<0.05)$. L-carnitines plasma level showed no significant differences among the three groups and L- Carnitine insufficiency was detected in $21.1 \%$ frail, $19.8 \%$ prefrail and $20.1 \%$ robust group, with no significant difference between the three groups $(p>0.05)$ as shown in Table 3 .

TABLE 1. Sociodemographic characteristics (Present as n (\%))

\begin{tabular}{|c|c|c|c|c|c|c|}
\hline & Factors & $\mathrm{N}$ & $\begin{array}{l}\text { Robust } \\
(n=30)\end{array}$ & $\begin{array}{l}\text { Prefrail } \\
(n=32)\end{array}$ & $\begin{array}{c}\text { Frail } \\
(n=29)\end{array}$ & $P$ value \\
\hline \multirow[t]{2}{*}{ Gender } & Men & 43 & $14(33)$ & $16(37)$ & $13(30)$ & 0.678 \\
\hline & women & 48 & $16(33.3)$ & $16(33.3)$ & $16(33.3)$ & \\
\hline \multirow[t]{2}{*}{ Age } & $60-70$ & 49 & $17(35)$ & 19(39) & $13(26)$ & 0.245 \\
\hline & $>70$ & 42 & $13(31)$ & $13(31)$ & $16(38)$ & \\
\hline \multirow[t]{2}{*}{ Ethnicity } & Malay and Indian & 40 & $12(30)$ & $16(40)$ & $12(30)$ & 0.517 \\
\hline & Chinese & 51 & $18(35)$ & $16(31)$ & $17(34)$ & \\
\hline \multirow[t]{2}{*}{ Marital status } & Married & 53 & $18(34)$ & $21(40)$ & $14(26)$ & 0.18 \\
\hline & Other & 38 & $12(32)$ & 11(29) & $15(39)$ & \\
\hline \multirow[t]{2}{*}{ Monthly income } & Low $<1500 \mathrm{rm}$ & 35 & 11(31) & $13(38)$ & $11(31)$ & 0.079 \\
\hline & Moderate- high $>1500 \mathrm{rm}$ & 56 & $19(34)$ & $19(34)$ & $18(32)$ & \\
\hline
\end{tabular}


TABLE 2. Biochemical profile according to frailty status and gender (presented as Mean $\pm \mathrm{SD}$ )

\begin{tabular}{lcccc}
\hline Tests & Unit & \multicolumn{3}{c}{ Total (91) } \\
\cline { 3 - 5 } & & $\begin{array}{c}\text { Robust } \\
(n=30)\end{array}$ & $\begin{array}{c}\text { Prefrail } \\
(n=32)\end{array}$ & $\begin{array}{c}\text { Frail } \\
(n=29)\end{array}$ \\
\hline FBG & $\mathrm{mmol} / \mathrm{L}$ & $6.00 \pm 1.6$ & $6.4 \pm 2.5$ & $5.6 \pm 0.71$ \\
Total cholesterol & $\mathrm{mmol} / \mathrm{L}$ & $5.2 \pm 1.1$ & $5.2 \pm 1.1$ & $5.1 \pm 0.9$ \\
HDL & $\mathrm{mmol} / \mathrm{L}$ & $1.5 \pm 0.3$ & $1.4 \pm 0.4$ & $1.4 \pm 0.6$ \\
LDL & $\mathrm{mmol} / \mathrm{L}$ & $3.2 \pm 0.9$ & $3.1 \pm 0.9$ & $2.9 \pm 0.8$ \\
Triglyceride & $\mathrm{mmol} / \mathrm{L}$ & $1.3 \pm 0.7$ & $1.5 \pm 0.8$ & $1.3 \pm 0.6$ \\
TC: HDL & --- & $3.8 \pm 1.0$ & $3.9 \pm 1.2$ & $3.5 \pm 0.9$ \\
Albumin & $\mathrm{g} / \mathrm{L}$ & $42.7 \pm 3.0$ & $42.8 \pm 3.1$ & $42.7 \pm 2.8$ \\
\hline
\end{tabular}

NS: no significant differences using Kruskal Wallis test.

Abbreviation: FBG: fasting blood glucose, $\mathrm{HDL}=$ high density lipoprotein, $\mathrm{LDL}=$ low density lipoprotein

TABLE 3. Frailty biomarkers and L-carnitine blood level, according to frailty status and gender (presented in Mean \pm SD)

\begin{tabular}{lcccccc}
\hline Tests & Unit & $\begin{array}{c}\text { Normal } \\
\text { range }\end{array}$ & $\begin{array}{c}\text { Robust } \\
(n=30)\end{array}$ & $\begin{array}{c}\text { Prefrail } \\
(n=32)\end{array}$ & Frail $(n=29)$ & P value \\
\hline Interleukin-6 (Il-6) & $\mathrm{pg} / \mathrm{mL}$ & & $5.4 \pm 2.2$ & $6.2 \pm 2.8$ & $10.6 \pm 5.4$ & $0.000^{* *}$ \\
Tumor necrosis factor - alpha TNF- $\alpha$ & $\mathrm{pg} / \mathrm{mL}$ & & $4.6 \pm 1.4$ & $6.2 \pm 1.8$ & $7.3 \pm 6.0$ & $0.017^{*}$ \\
Insuline like growth factor (IGF-1) & $\mathrm{ng} / \mathrm{mL}$ & $(47-190)$ & $62.1 \pm 16.5$ & $51.3 \pm 13.1$ & $50.7 \pm 19.7$ & 0.212 \\
Vitamin D & $\mathrm{ng} / \mathrm{mL}$ & $>25$ & $23.4 \pm 7.7$ & $17.3 \pm 4.6$ & $16.2 \pm 7.5$ & $0.035^{*}$ \\
Free Carnitine & $\mu \mathrm{mol} / \mathrm{L}$ & & $33.3 \pm 2.1$ & $32.1 \pm 9.2$ & $33.6 \pm 2.9$ & 0.197 \\
Acetyl Carnitine & $\mu \mathrm{mol} / \mathrm{L}$ & & $7.4 \pm 4.2$ & $6.2 \pm 5.4$ & $7.1 \pm 5.3$ & 0.383 \\
Total Carnitine & $\mu \mathrm{mol} / \mathrm{L}$ & & $40.6 \pm 4.0$ & $39.2 \pm 4.6$ & $40.7 \pm 3.9$ & 0.651 \\
Free carnitine: Acetyl carnitine & & & $0.226 \pm 0.13$ & $0.281 \pm 0.36$ & $0.22 \pm 0.18$ & 0.585 \\
\hline
\end{tabular}

*significant at $\mathrm{p}<0.05$ using Kruskal Wallis test.

Abbreviations: IL-6: interleukin 6, TNF- $\alpha$ : tumor necrosis factor - alpha, IGF-1: Insuline like growth factor

Results from binary logistic regression indicated that vitamin D deficiency increased risk of frailty by three times, after adjustment for age and gender (OR 3.69, 95\% CI, $p<0.01$ ), and higher level of Interleukin -6 increase the risk of frailty (OR 1.2, 95\%, $<<0.05$ ), as shown in Table 4 .

Blood indicators, such as albumin, lipid profile, fasting blood glucose and vitamin $\mathrm{D}$, were assessed in the light of their relationship with frailty. Albumin was used in clinical setting to predict mortality in elderly and better health and nutritional status (Schalk et al. 2004) and associated with better functional performance in older adults (Villareal et al. 2004). However, in the current study, albumin blood level did not show significant relationship with frailty. The non-significant results might be due to normal albumin blood level in all of study subjects.

Similar to albumin, there were no significant differences in the means of the lipid profile and fasting blood glucose between the frail group and the others. However, there was a significant association between the lower level of high density lipoproteins (HDL) with being frail/prefrail; low blood level of HDL associated with double risk to develop frailty. Villareal et al. (2004) did not find any significant difference in the means of any of the lipid profile tests between frail and non-frail elderly. Fried et al (2001) reported an association between frailty and cardiovascular diseases. This highlights the importance for conducting more research to identify the relationship between frailty and other chronic diseases and their impact on elderly health.

Vitamin D, as a frailty biomarker and nutritional status parameter, was found to be lower in frail and prefrail subjects as compared to robust. This is also reported by other researchers (Chang et al 2010; Puts et al. 2005; Vogt et al. 2015). Vitamin D has a primary physiological role in human body. It is involved in many metabolic processes and pathways (Mithal et al. 2009). In elderly, it was found that vitamin D status could predict the decline in the physical performance (Wicherts et al. 2007); and it was related to falls risk, fracture rate and rate of bone loss among the elderly (Dawson-Hughes et al. 2005). Frailty definition includes physical function impairment and metabolic changes. Similarly, vitamin D deficiency also leads to physical function impairment and metabolic changes (Vogt et al. 2015).

Frailty biomarkers reported in the literature including the inflammatory mediators (IL-6 and TNF- $\alpha$ ) and the anabolic hormone (IGF-1) were determined and investigated in association with frailty. These biomarkers 
TABLE 4. Frailty predictors from selected biomarkers

\begin{tabular}{lccccc}
\hline Factors & B & Pvalue & $\operatorname{Exp}(\mathrm{B})$ & $\operatorname{Exp}(\mathrm{B})$ & $\mathrm{P}$ \\
\hline Age & 0.13 & $0.012^{*}$ & 1.12 & 2.63 & $0.000^{* *}$ \\
Gender & 0.167 & 0.764 & 1.12 & & \\
$\begin{array}{l}\text { Vitamin D }<25 \\
(\mathrm{ng} / \mathrm{mL})\end{array}$ & 1.25 & $0.034^{*}$ & 3.69 & & \\
$\mathrm{TNF} \alpha$ & & & & & \\
(pg/mL) & 0.13 & 0.058 & 1.1 & & \\
$\begin{array}{l}\mathrm{IGF}-1 \\
(\mathrm{ng} / \mathrm{mL})\end{array}$ & -0.09 & 0.07 & 0.9 & & \\
$\begin{array}{l}\mathrm{IL}-6 \\
(\mathrm{pg} / \mathrm{mL})\end{array}$ & 0.127 & 0.02 & 1.2 & & \\
\hline
\end{tabular}

Cox \& Snell R square $=0.157$ and Nagelkerke $\mathrm{R}$ square $=0.2 .91$

Abbreviations: IL-6: interleukin 6, TNF- $\alpha$ : tumor necrosis factor - alpha, IGF-1: Insulin like growth factor.

** Significant at $\mathrm{p}<0.01$ using Binary logistic regression test

were analyzed in a sub-sample from the total participants. The results showed a significantly higher serum level of IL- 6 and TNF- $\alpha$ in frail subjects as compared to prefrail and robust. The level of the anabolic hormone IGF-1 was lower in frail compared to prefrail and robust, but it did not reach the significant level. Serum level of the inflammatory cytokines IL- 6 was correlated with changes in body composition, disability and morbidity related to aging (Walston et al. 2005). In many other studies higher levels of IL- 6 and other proinflammatory cytokines were reported in frail compared to robust and prefrail (Collerton et al. 2012; Hubbard \& Woodhouse 2010; Walston et al. 2005) community dwelling older adults. Collerton et al. (2012) reported that IL-6 was a significant predictor of frailty status among the very old older adults aged 85 years and above. Similar findings were reported among institutionalized older adults in long term care facilities (Lai et al. 2014). All of these findings support the hyper inflammation theory of pathophysiological changes in frailty. Tumor necrosis factor - alpha (TNF- $\alpha$ ), is another pro inflammatory cytokines, that usually increases with normal aging (de Gonzalo-Calvo et al. 2010), and in age related diseases like Alzheimer (Cheng et al. 2014). TNF- $\alpha$ has been studied in the light of its relationship with frailty, but the results were not consistent as in IL-6. Our study results also showed a significant higher serum level of the TNF- $\alpha$ in frail compared to prefrail and robust. This was contradictory to the reports in other studies that did not find a significant association between frailty and TNF- $\alpha$ (Collerton et al. 2012; Hubbard \& Woodhouse 2010; Lai et al. 2014).

Changes in the hormones and hormone response in aging are documented and correlated with age related diseases (Ferrari \& Magri 2008; Marzetti et al. 2013). Decline in anabolic hormones such as growth hormone and insulin like growth factor (IGF-1) is also documented. This decline was associated with sarcopenia, cognitive decline and other disorders (Jones \& Boelaert 2015). Even though this study did not find a significant difference in the level of IGF-1 among frail, prefrail and robust groups, there was a trend for its decline with frailty. Leng et al. (2009) found a significant association between frailty and low level of IGF-1 in older women with moderate to severe disability. Moreover, in a recent study conducted among outpatients' older men, a significant relationship with frailty was found (Mohammed \& Khater 2015). The differences between the results of our study and previous studies is probably due to the difference in participants' selection, analysis methods and sample size.

The relationship between L-carnitine and frailty was proposed from the similarities between L-carnitine deficiency and pathophysiological changes that occurred in frailty, namely abnormalities in energy metabolism, inflammation and impaired in immune function (Crentsil 2010). L-carnitine supplementation improved muscle function (Rivero et al. 2002), decreased fatigue (Cavallini et al. 2004; Malaguarnera et al. 2007), improved body composition and regulated inflammation process (Pertosa et al. 2005). To the best of our knowledge, there have been no studies published in the searched databases reporting the relationship between L-carnitine and frailty. Even our study failed to provide evidence for the relationship between the L-carnitine and acyle carnitine with frailty. The non-significant results in our study may be due to the small sample size, majority of the participants been well nourished as micronutrients deficiency affects the ability of the body to synthesize L-carnitine. There is a need for further research to examine this relationship by including all the susceptible mechanisms that may involve in frailty such as CPTII enzyme and OCTN2 mutation or functional decline.

\section{CONCLUSION}

Frailty was associated with hyper inflammatory status as indicated by the significant higher level of serum IL- 6 and TNF- $\alpha$ ). Vitamin D deficiency increased the risk of frailty by three times. Chronic disease management, healthy lifestyle 
behavior and diet are important to improve vitamin D status and inflammatory markers in order to prevent frailty among older adults.

\section{ACKNOWLEDGEMENTS}

We would like to acknowledge the financial support from the Ministry of Education via Long Term Research Grant Scheme (LRGS/BU/2012/UKM-UKM/K/01) and the input from all the research team. We would also like to thank all older adults who participated and provided full cooperation during the data collection and assessment in our study. The authors report no conflicts of interest in this work.

\section{REFERENCES}

Almeida, O.P., Norman, P.E., van Bockxmeer, F.M., Hankey, G.J. \& Flicker, L. 2012. CRP 1846G A polymorphism increases risk of frailty. Maturitas 71(3): 261-266.

Annweiler, C., Bataille, R., Ferrière, N., Douillet, D., Fantino, B. \& Beauchet, O. 2011. Plasma beta-2 microglobulin as a marker of frailty in older adults: A pilot study. The Journals of Gerontology Series A: Biological Sciences and Medical Science 66(10): 1077-1079.

Ble, A., Cherubini, A., Volpato, S., Bartali, B., Walston, J.D., Windham, B.G. \& Ferrucci, L. 2006. Lower plasma vitamin E levels are associated with the frailty syndrome: The InCHIANTI study. The Journals of Gerontology Series A: Biological Sciences and Medical Sciences 61(3): 278-283.

Brass, E.P., Adler, S., Sietsema, K.E., Hiatt, W.R., Orlando, A.M. \& Amato, A. 2001. Intravenous L-carnitine increases plasma carnitine, reduces fatigue, and may preserve exercise capacity in hemodialysis patients. American Journal of Kidney Diseases 37(5): 1018-1028.

Byard, R.W. 2015. Frailty syndrome-medicolegal considerations. Journal of Forensic and Legal Medicine 30: 34-38.

Calabrese, V., Stella, A.M.G., Calvani, M. \& Butterfield, D.A. 2006. Acetylcarnitine and cellular stress response: Roles in nutritional redox homeostasis and regulation of longevity genes. Journal of Nutritional Biochemistry 17(2): 73-88.

Campos, Y., Arenas, J., Cabello, A. \& Gomez-Reino, J.J. 1995. Respiratory chain enzyme defects in patients with idiopathic inflammatory myopathy. Annals of the Rheumatic Diseases 54(6): 491-493.

Cavallini, G., Caracciolo, S., Vitali, G., Modenini, F. \& Biagiotti, G. 2004. Carnitine versus androgen administration in the treatment of sexual dysfunction, depressed mood, and fatigue associated with male aging. Urology 63(4): 641-646.

Chang, C.I., Chan, D.C.D., Kuo, K.N., Hsiung, C.A. \& Chen, C.Y. 2010. Vitamin D insufficiency and frailty syndrome in older adults living in a Northern Taiwan community. Archives of Gerontology and Geriatrics 50: 17-21.

Cheng, X., Shen, Y. \& Li, R. 2014. Targeting TNF: A therapeutic strategy for Alzheimer's disease. Drug Discovery Today 19(11): 1822-1827.

Chung, H.Y., Cesari, M., Anton, S., Marzetti, E., Giovannini, S., Seo, A.Y. \& Leeuwenburgh, C. 2009. Molecular inflammation: Underpinnings of aging and age-related diseases. Ageing Research Reviews 8(1): 18-30.

Collerton, J., Martin-Ruiz, C., Davies, K., Hilkens, C.M., Isaacs, J., Kolenda, C. \& Jagger, C. 2012. Frailty and the role of inflammation, immunosenescence and cellular ageing in the very old: Cross-sectional findings from the Newcastle $85+$
Study. Mechanisms of Ageing and Development 133(6): 456-466.

Crentsil, V. 2010. Mechanistic contribution of carnitine deficiency to geriatric frailty. Ageing Research Reviews 9(3): 265-268.

Dawson-Hughes, B., Heaney, R.P., Holick, M.F., Lips, P., Meunier, P.J. \& Vieth, R. 2005. Estimates of optimal vitamin D status. Osteoporosis International 16(7): 713-716.

de Gonzalo-Calvo, D., Neitzert, K., Fernández, M., Vega-Naredo, I., Caballero, B., García-Macía, M. \& Coto-Montes, A. 2010. Differential inflammatory responses in aging and disease: TNF- $\alpha$ and IL- 6 as possible biomarkers. Free Radical Biology and Medicine 49(5): 733-737.

Fernández-Garrido, J., Ruiz-Ros, V., Buigues, C., NavarroMartinez, R. \& Cauli, O. 2014. Clinical features of prefrail older individuals and emerging peripheral biomarkers: A systematic review. Archives of Gerontology and Geriatrics 59(1): 7-17.

Ferrari, E. \& Magri, F. 2008. Role of neuroendocrine pathways in cognitive decline during aging. Ageing Research Reviews 7(3): 225-233.

Field, A. 2013. Discovering Statistics using IBM SPSS Statistics. 4th ed. London: SAGE Publications Ltd.

Fried, L.P., Tangen, C.M., Walston, J., Newman, A.B., Hirsch, C., Gottdiener, J. \& Burke, G. 2001. Frailty in older adults evidence for a phenotype. The Journals of Gerontology Series A: Biological Sciences and Medical Sciences 56(3): M146-M157.

García-Esquinas, E., Navas-Acien, A., Pérez-Gómez, B. \& Artalejo, F.R. 2015. Association of lead and cadmium exposure with frailty in US older adults. Environmental Research 137: 424-431.

Hall, J.A. \& Jewell, D.E. 2012. Feeding healthy beagles mediumchain triglycerides, fish oil, and carnitine offsets age-related changes in serum fatty acids and carnitine metabolites. PloS ONE 7(11): e49510.

Hubbard, R.E. \& Woodhouse, K.W. 2010. Frailty, inflammation and the elderly. Biogerontology 11(5): 635-641.

Jones, C. \& Boelaert, K. 2014. The endocrinology of ageing: A mini-review. Gerontology 61(4): 291-300.

Kumar, R., Mohan, N., Upadhyay, A.D., Singh, A.P., Sahu, V., Dwivedi, S. \& Dey, S. 2014. Identification of serum sirtuins as novel noninvasive protein markers for frailty. Aging Cell 13(6): 975-980.

Lai, H.Y., Chang, H.T., Lee, Y.L. \& Hwang, S.J. 2014. Association between inflammatory markers and frailty in institutionalized older men. Maturitas 79(3): 329-333.

Lang, P., Mitchell, W., Lapenna, A., Pitts, D. \& Aspinall, R. 2010. Immunological pathogenesis of main age-related diseases and frailty: Role of immunosenescence. European Geriatric Medicine 1(2): 112-121.

Leng, S.X., Hung, W., Cappola, A.R., Yu, Q., Xue, Q.L. \& Fried, L.P. 2009. White blood cell counts, insulin like growth factor-1 levels, and frailty in community-dwelling older women. The Journals of Gerontology Series A: Biological Sciences and Medical Sciences 64(4): 499-502.

Malaguarnera, M., Cammalleri, L., Gargante, M.P., Vacante, M., Colonna, V. \& Motta, M. 2007. L-Carnitine treatment reduces severity of physical and mental fatigue and increases cognitive functions in centenarians: A randomized and controlled clinical trial. The American Journal of Clinical Nutrition 86(6): 1738-1744.

Marzetti, E., Calvani, R., Cesari, M., Buford, T.W., Lorenzi, M., Behnke, B.J. \& Leeuwenburgh, C. 2013. Mitochondrial 
dysfunction and sarcopenia of aging: From signaling pathways to clinical trials. The International Journal of Biochemistry \& Cell Biology 45(10): 2288-2301.

Mithal, A., Wahl, D., Bonjour, J.P., Burckhardt, P., DawsonHughes, B., Eisman, J. \& Morales-Torres, J. 2009. Global vitamin D status and determinants of hypovitaminosis D. Osteoporosis International 20(11): 1807-1820.

Mocchegiani, E., Corsonello, A. \& Lattanzio, F. 2010. Frailty, ageing and inflammation: Reality and perspectives. Biogerontology 11(5): 523-525.

Mohamad, M.I. \& Khater, M.S. 2015. Evaluation of insulin like growth factor-1 (IGF-1) level and its impact on muscle and bone mineral density in frail elderly male. Archives of Gerontology and Geriatrics 60(1): 124-127.

Pertosa, G., Grandaliano, G., Simone, S., Soccio, M. \& Schena, F.P. 2005. Inflammation and carnitine in hemodialysis patients. Journal of Renal Nutrition 15(1): 8-12.

Prieto, J.A., Andrade, F., Aldámiz-Echevarría, L. \& Sanjurjo, P. 2006. Determination of free and total carnitine in plasma by an enzymatic reaction and spectrophotometric quantitation spectrophotometric determination of carnitine. Clinical Biochemistry 39(10): 1022-1027.

Puts, M.T., Visser, M., Twisk, J.W., Deeg, D.J. \& Lips, P. 2005. Endocrine and inflammatory markers as predictors of frailty. Clinical Endocrinology 63(4): 403-411.

Rivero, J.L., Sporleder, H.P., Quiroz-Rothe, E., Vervuert, I., Coenen, M. \& Harmeyer, J. 2002. Oral L-carnitine combined with training promotes changes in skeletal muscle. Equine Veterinary Journal 34: 269-274.

Rockwood, K., Andrew, M. \& Mitnitski, A. 2007. A comparison of two approaches to measuring frailty in elderly people. The Journals of Gerontology Series A: Biological Sciences and Medical Sciences 62(7): 738-743.

Saum, K.U., Dieffenbach, A.K., Müezzinler, A., Müller, H., Holleczek, B., Stegmaier, C. \& Stammer, H. 2014. Frailty and telomere length: Cross-sectional analysis in 3537 older adults from the ESTHER cohort. Experimental Gerontology 58: 250-255.

Schalk, B.W., Visser, M., Deeg, D.J. \& Bouter, L.M. 2004. Lower levels of serum albumin and total cholesterol and future decline in functional performance in older persons: The Longitudinal Aging Study Amsterdam. Age and Ageing 33(3): 266-272.

Shahar, S., Omar, A., Vanoh, D., Hamid, T.A., Mukari, S.Z.M.S., Din, N.C. \& Loo, W.H. 2015. Approaches in methodology for population-based longitudinal study on neuroprotective model for healthy longevity (TUA) among Malaysian older adults. Aging Clinical and Experimental Research 28(6): 1089-1104.

Shamsi, K.S., Pierce, A., Ashton, A.S., Halade, D.G., Richardson, A. \& Espinoza, S.E. 2012. Proteomic screening of glycoproteins in human plasma for frailty biomarkers. The Journals of Gerontology Series A: Biological Sciences and Medical Sciences 67(8): 853-864.

Villareal, D.T., Banks, M., Siener, C., Sinacore, D.R. \& Klein, S. 2004. Physical frailty and body composition in obese elderly men and women. Obesity Research 12(6): 913-920.
Vogt, S., Decke, S., de las Heras Gala, T., Linkohr, B., Koenig, W., Ladwig, K.H., Peters, A. \& Thorand, B. 2015. Prospective association of vitamin D with frailty status and all-cause mortality in older adults-Results from the KORA-Age Study. Preventive Medicine 73: 40-46.

Walston, J., Arking, D., Fallin, D., Li, T., Beamer, B., Xue, Q. \& Chakravarti, A. 2005. IL-6 gene variation is not associated with increased serum levels of IL-6, muscle, weakness, or frailty in older women. Experimental Gerontology 40(4): 344-352.

Weiss, C.O. 2011. Frailty and chronic diseases in older adults. Clinics in Geriatric Medicine 27(1): 39-52.

Wicherts, I.S., van Schoor, N.M., Boeke, A.J.P., Visser, M., Deeg, D.J., Smit, J. \& Lips, P. 2007. Vitamin D status predicts physical performance and its decline in older persons. The Journal of Clinical Endocrinology \& Metabolism 92(6): 2058-2065.

Manal Badrasawi \& Suzana Shahar*

Dietetic, Programme and Centre for Healthy Aging and Wellness Faculty of Health Sciences

Universiti Kebangsaan Malaysia

Jalan Raja Muda Abdul Aziz

50300 Kuala Lumpur, Federal Territory

Malaysia.

Manal Badrasawi

Nutrition and Food Technology

Faculty of Agriculture

An-Najah National University

Palestine

Nor Fadilah Rajab

Biomedical Programme and Centre of Healthy Aging and Wellness

Faculty of Health Science, School of Healthcare Sciences

Universiti Kebangsaan Malaysia

Jalan Raja Muda Abdul Aziz

50300 Kuala Lumpur, Federal Territory

Malaysia

Devinder Kaur Ajit Singh

Physiotherapy Programme and Centre for Rehabilitation and Special Needs

Faculty of Health Sciences

Universiti Kebangsaan Malaysia

Jalan Raja Muda Abdul Aziz

50300 Kuala Lumpur, Federal Territory

Malaysia

*Corresponding author; email: suzana.shahar@ukm.edu.my

Received: 24 April 2018

Accepted: 9 January 2019 